\title{
PROVING RELIABILITY AND REPRODUCIBILITY OF THE TECHNOLOGY FOR GRAFTING AND CROSSLINKING BLENDS BASED ON ETHYLENE VINYL ACETATE COPOLYMER AND TRIALLYL CYANURATE BY ELECTRON BEAM IRRADIATION, USING STATISTICAL ANALYSIS OF EXPERIMENTAL DATA OBTAINED
}

\author{
DEMONSTRAREA FIABILITĂTII ŞI REPRODUCTIBILITĂTII TEHNOLOGIEI DE GREFARE ŞI RETICULARE A \\ UNOR AMESTECURI PE BAZĂ DE COPOLIMER ETILENĂ-ACETAT DE VINIL ŞI TRIALILCIANURAT PRIN \\ IRADIERE CU ELECTRONI ACCELERATI, UTILIZÂND ANALIZA STATISTICĂ A DATELOR EXPERIMENTALE \\ OBTINUTE
}

\author{
Elena MANAILA ${ }^{1}$, Maria Daniela STELESCU² ${ }^{2}$, Gabriela Ileana NICULESCU-ARON ${ }^{3}$, Dana GURAU ${ }^{2}$ \\ ${ }^{1}$ National Institute for Laser, Plasma and Radiation Physics, Electron Accelerators Laboratory, 409 Atomistilor St., 077125 Magurele, Romania \\ ${ }^{2}$ National Research \& Development Institute for Textiles and Leather, Division: Leather \& Footwear Research Institute, 93 Ion Minulescu St., \\ 031215, Bucharest, Romania, e-mail: dmstelescu@yahoo.com \\ ${ }^{3}$ Academy of Economic Studies, Faculty of Cybernetics, Statistics \& Economic Informatics, 15-17 Calea Dorobantilor, 010552, Bucharest, \\ Romania
}

\begin{abstract}
PROVING RELIABILITY AND REPRODUCIBILITY OF THE TECHNOLOGY FOR GRAFTING AND CROSSLINKING BLENDS BASED ON ETHYLENE VINYL ACETATE COPOLYMER AND TRIALLYL CYANURATE BY ELECTRON BEAM IRRADIATION, USING STATISTICAL ANALYSIS OF EXPERIMENTAL DATA OBTAINED

ABSTRACT. The paper presents our experiments regarding the demonstration of reliability and reproducibility of the technology for grafting and crosslinking blends of ethylene vinyl acetate copolymer (EVA) and triallyl cyanurate polyfunctional monomer (TAC) by electron beam irradiation (EB). Blends based on EVA and TAC were irradiated with different doses of EB. The physical-mechanical properties of the irradiated samples were compared with those of samples obtained by classic crosslinking in the presence of peroxides. Experimental data obtained were processed and statistical analysis was performed using SPSS version 13 and regression models were established. Depending on the dose of irradiation, characteristics of the blends were estimated with a probability of $95 \%$ based on established regression models. The results have shown that the technology is reproducible and reliable.

KEY WORDS: EVA, TAC, electron beam, physical-mechanical characteristics, regression model, estimation of variables
\end{abstract}

DEMONSTRAREA FIABILITĂTII ŞI REPRODUCTIBILITĂTJII TEHNOLOGIEI DE GREFARE ŞI RETICULARE A UNOR AMESTECURI PE BAZĂ DE COPOLIMER ETILENĂACETAT DE VINIL ŞI TRIALILCIANURAT PRIN IRADIERE CU ELECTRONI ACCELERATI, UTILIZÂND ANALIZA STATISTICĂ A DATELOR EXPERIMENTALE OBTINUTE REZUMAT. Articolul prezintă experimentările noastre privind demonstrarea fiabilităţii şi reproductibilităţii tehnologiei de grefare şi reticulare a amestecurilor de copolimer etilenă-acetat de vinil (EVA) şi monomer polifuncţional trialilcianurat (TAC) prin iradiere cu electroni acceleraţi (EA). Amestecurile pe bază de EVA şi TAC au fost iradiate cu diferite doze de EA. Caracteristicile fizico-mecanice ale probelor iradiate au fost comparate cu acelea ale probelor obţinute prin reticularea clasică în prezenţa peroxizilor. S-a realizat procesarea şi analiza statistică a datelor experimentale obţinute utilizând programul SPSS versiunea 13 şi s-au stabilit modelele de regresie. În funcţie de doza de iradiere au fost estimate caracteristicile amestecului cu o probabilitate de 95\% pe baza modelelor de regresie stabilite. Rezultatele obţinute au demonstrat faptul că tehnologia este reproductibilă şi fiabilă.

CUVINTE CHEIE: EVA, TAC, electroni acceleraţi, caracteristici fizico-mecanice, model de regresie, estimarea variabilelor.

LA DÉMONSTRATION DE LA FIABILITÉ ET DE LA REPRODUCTIBILITÉ DE LA TECHNOLOGIE DE GREFFAGE ET DE RÉTICULATION DE CERTAINS MÉLANGES À BASE D'ÉTHYLÈNE-ACÉTATE DE VINYLE ET CYANURATE DE TRIALLYLE PAR IRRADIATION PAR UN FAISCEAU D'ÉLECTRONS, EN UTILISANT L'ANALYSE STATISTIQUE DES DONNÉES EXPÉRIMENTALES OBTENUES

RÉSUMÉ. Cet article présente nos expériences pour démontrer la fiabilité et la reproductibilité de la technologie de greffage et de réticulation des mélanges d'éthylène-acétate de vinyle (EVA) et monomère multifonctionnel cyanurate de triallyle (TAC) par irradiation par un faisceau d'électrons. Les mélanges à base de EVA et TAC ont été irradiés avec différentes doses de EA. Les propriétés physico-mécaniques des échantillons irradiés ont été comparés à celles des échantillons obtenus par la réticulation classique en présence de peroxydes. On a fait le traitement et l'analyse statistique des données expérimentales en utilisant SPSS version 13 et on a établi des modèles de régression. En fonction de la dose d'irradiation on a estimé les caractéristiques du mélange avec une probabilité de $95 \%$ à partir des modèles de régression déterminés. Les résultats ont montré que la technologie est reproductible et fiable.

MOTS CLÉS: EVA, TAC, faisceau d'électrons, caractéristiques physico-mécaniques, modèle de régression, estimation des variables.

* Correspondence to: Maria Daniela STELESCU, National Research \& Development Institute for Textiles and Leather, Division: Leather \& Footwear Research Institute, 93 Ion Minulescu St., 031215, Bucharest, Romania, e-mail: dmstelescu@yahoo.com 


\section{INTRODUCTION}

The radiation induced grafting and crosslinking of polymers are new techniques applied in modifying polymers. Use of radiations as power source is justified by the limited classic resources, on the one hand, and a number of specific benefits, on the other hand, such as: (1) removing the curing agents, (2) obtaining new high purity materials, (3) a fast process which enables an accurate monitoring, (4) an effective and uniform curing of the whole rubber body because of the high penetrating ability of radiation, (5) lack of wastes [1-11].

For this reason, it is important to analyze the properties of blends irradiated with electron beam according to the irradiation intensity, so as to obtain a product with characteristics comparable to those obtained by classical crosslinking by means of peroxides.

This paper deals with ethylene vinyl acetate copolymer (EVA) crosslinking and grafting by using electron beam (EB) irradiation in the presence of a polyfunctional monomer such as TAC. Physicalmechanical characteristics of the samples irradiated with various $E B$ doses were compared with those of the sample obtained by classical crosslinking in the presence of peroxides. The resulting data were subjected to processing and statistical analysis to show the reliability and reproducibility of the EVA crosslinking and grafting technology by means of EB.

\section{EXPERIMENTAL}

\section{Materials}

Materials used in the study: (1) ethylene vinyl acetate copolymers Elvax $260 \quad(27.8 \%$ wt\% vinyl acetate content, flow index $5.5 \mathrm{~g} / 10 \mathrm{~min}$ at $190^{\circ} \mathrm{C}$ and $2.16 \mathrm{~kg}$ load), (2) antioxidant Irganox 1010, (3) dibenzoyl peroxide Perkadox 14-40B $\left(1.60 \mathrm{~g} / \mathrm{cm}^{3}\right.$ density, $3.8 \%$ active oxygen content, $40 \%$ peroxide content, $\mathrm{pH} 7$ ) as vulcanizing agent for vulcanization of control samples and (4) polyfunctional monomer triallylcyanurate Luvomaxx TAC DL 70 (26\% percentage of ash, density $1.34 \mathrm{~g} / \mathrm{cm}^{3}, 30 \%$ active synthetic silica).

\section{INTRODUCERE}

Grefarea şi reticularea polimerilor cu ajutorul radiaţiilor este o tehnică nouă de modificare a polimerilor. Folosirea radiaţiilor ca sursă de energie este justificată pe de o parte de limitarea resurselor clasice şi pe de altă parte de o serie de avantaje specifice, cum ar fi: (1) eliminarea agenţilor de vulcanizare; (2) obţinerea de noi materiale cu grad înalt de puritate; (3) procesul este foarte rapid şi poate fi controlat cu precizie; (4) datorită puterii mari de penetrare a radiaţiilor, are loc 0 vulcanizare eficientă şi uniformă în toată masa articolelor de cauciuc; (5) nu se obţin deşeuri [1-11].

Din această cauză este important să analizăm proprietăţile amestecurilor iradiate cu electroni acceleraţi în funcţie de intensitatea iradierii astfel încât să obţinem un produs cu caracteristici comparabile cu cele obţinute prin procedeul clasic de reticulare cu ajutorul peroxizilor.

Acest articol se referă la reticularea şi grefarea amestecurilor de copolimer etilenă-acetat de vinil (EVA) prin iradiere cu electroni acceleraţi (EA), în prezenţa unui monomer polifuncţional, cum ar fi trialilcianurat (TAC). Caracteristicile fizico-mecanice ale probelor iradiate cu diferite doze de EA au fost comparate $\mathrm{cu}$ acelea ale probelor obţinute prin reticularea clasică în prezenţa peroxizilor. Datele experimentale au fost procesate şi analizate statistic pentru a demonstra fiabilitatea şi reproductibilitatea tehnologiei de reticulare şi grefare cu EA.

\section{PARTEA EXPERIMENTALĂ}

\section{Materiale}

Materiale utilizate în studiu: (1) copolimeri etilenă-acetat de vinil Elvax 260 (27,8\% wt\% conţinut de acetat de vinil, indice de curgere $5,5 \mathrm{~g} / 10 \mathrm{~min}$ la $190^{\circ} \mathrm{C}$ cu apăsare de $2,16 \mathrm{~kg}$ ), (2) antioxidant Irganox 1010, (3) peroxid de dibenzoil Perkadox 14-40B (densitate $1,60 \mathrm{~g} / \mathrm{cm}^{3}$, conţinut oxigen activ $3,8 \%$, conţinut de peroxid $40 \%$, pH 7) ca agent de vulcanizare pentru probele martor şi (4) monomer polifuncţional trialilcianurat Luvomaxx TAC DL 70 (procent de cenuşă $26 \%$, densitate $1,34 \mathrm{~g} / \mathrm{cm}^{3}, 30 \%$ dioxid de siliciu sintetic activ). 


\section{Sample Preparation}

Blends were prepared by means of blending technique, on a electrically heated laboratory roller mill. The blend constituents were added in the following sequence and amounts: 100 phr EVA and 3 phr TAC polyfunctional monomer. Process variables: temperature $70 \pm 5^{\circ} \mathrm{C}$, friction $1: 1.1$, and total blending time 6 min.

Plates required for physico-mechanical tests have been made by compression molding, using an electrically heated hydraulic press, at a temperature of $120^{\circ} \mathrm{C}$, pressure of $150 \mathrm{MPa}$ and time of $5 \mathrm{~min}$. to obtain sheets of dimension $11.5 \times 11.5 \times 0.2 \mathrm{~cm}^{3}$.

Dibenzoyl peroxide vulcanized samples were prepared similarly to the experimental ones with the following specifications: $8 \mathrm{phr}$ of dibenzoyl peroxide as vulcanizing agent were added and the blend vulcanization was achieved in a hydraulic press at $160^{\circ} \mathrm{C}$ and pressure of $150 \mathrm{MPa}$; the vulcanization time was measured by means of Monsanto Rheometer.

\section{Electron Beam Irradiation}

The samples were packed in a polyethylene film and were irradiated at doses ranging from 2 to $25 \mathrm{Mrad}$ (1 Mrad = $10 \mathrm{~Gy}$ ) in the ALIN-10 electron accelerator under atmospheric conditions and at room temperature. The ALIN-10 electron accelerator was built in Romania, National Institute for Lasers, Plasma and Radiation Physics, Electron Accelerator Laboratory - Bucharest. The optimum values of the EB peak current $I_{E B}$ and $E B$ energy $E_{E B}$ to produce maximum output power $P_{E B}$ for a fixed pulse duration ${ }_{E B}$ and repetition frequency $\mathrm{f}_{\mathrm{EB}}$ are as follows: $E_{\mathrm{EB}}=6.23 \mathrm{MeV} ; \mathrm{I}_{\mathrm{EB}}=75 \mathrm{~mA}$; $P_{E B}=164 \mathrm{~W}\left(f_{E B}=100 \mathrm{~Hz}\right.$, EB $\left.=3.5 \mathrm{~s}\right)$. The EB effects are related to the absorbed dose, D, expressed in Gray (1 Gy $=1 \mathrm{~J} / \mathrm{kg}, 10 \mathrm{~Gy}=1 \mathrm{Mrad}$ ) and absorbed dose rate, $\mathrm{D}^{*}$, expressed in $\mathrm{Gy} / \mathrm{s}$.

\section{Laboratory Tests}

Hardness in Shore A was measured by means of a hardness tester according to ISO 7619-1/2011. Tensile properties were measured by means of a Schopper strength tester. Tensile strength was determined using dumb-bell shaped specimens according to ISO $37 / 2012$. Tear strength was measured according to SR

\section{Pregătirea probelor}

Amestecurile au fost pregătite prin tehnica amestecării în topitură, pe un valţ de laborator cu încălzire electrică. Constituenţii amestecului s-au adăugat în următoarele cantităţi, în ordinea prezentată în continuare: 100 phr EVA şi 3 phr monomer polifunç̧ional TAC. Parametrii de lucru: temperatura de lucru $70 \pm 5^{\circ} \mathrm{C}$, friç̧ia 1:1.1 şi timpul total de amestecare $6 \mathrm{~min}$.

Epruvetele pentru testele fizico-mecanice s-au obţinut prin modelare prin compresie, folosind o presă hidraulică încălzită electric, la o temperatură de $120^{\circ} \mathrm{C}$, presiune de $150 \mathrm{MPa}$ şi timp de $5 \mathrm{~min}$. pentru a obţine foi cu dimensiunea de $11,5 \times 11,5 \times 0,2 \mathrm{~cm}^{3}$.

Probele vulcanizate cu peroxid de dibenzoil s-au pregătit în mod similar, cu următoarele specificaţii: s-au adăugat 8 phr de peroxid de dibenzoil ca agent de vulcanizare, iar vulcanizarea amestecului a fost realizată într-o presă hidraulică la $160^{\circ} \mathrm{C}$ şi o presiune de $150 \mathrm{MPa}$, timpul de vulcanizare a fost determinat $\mathrm{cu}$ ajutorul unui reometru Monsanto.

\section{Iradiere cu electroni acceleraţi}

Probele au fost învelite în film de polietilenă şi iradiate la doze de 2 până la 25 Mrad (1 Mrad = 10 Gy) utilizând acceleratorul de electroni ALIN-10 în condiţii atmosferice şi la temperatura camerei. ALIN-10 este un accelerator de electroni construit în România, la Institutul Naţional de Fizica Laserilor, Plasmei şi Radiaţiei, Laboratorul Acceleratori de electroni. Valorile optime pentru curentul de vârf al $E A, I_{E A}$, şi energia $E A, E_{E A}$, la care se obţine puterea maximă de fascicul, $P_{E A}$ pentru o durată a impulsului ${ }_{E A}$, şi o frecvenţă de repetiţie $f_{E A}$, sunt următoarele: $\mathrm{E}_{\mathrm{EA}}=6.23 \mathrm{MeV} ; \mathrm{I}_{\mathrm{EA}}=75 \mathrm{~mA} ; \mathrm{P}_{\mathrm{EA}}=164 \mathrm{~W}\left(\mathrm{f}_{\mathrm{EA}}=\right.$ $100 \mathrm{~Hz}$, EA $=3.5 \mathrm{~s})$. Efectele EB sunt redate prin doza absorbită (D) exprimată în Gray (1 Gy = 1 J/kg, 10 Gy = 1 Mrad) şi debitul dozei absorbite ( $\left.D^{*}\right)$ exprimate în $G y / s$ sau J/kg*s.

\section{Teste de laborator}

Duritatea Shore A s-a măsurat cu ajutorul unui durometru conform ISO 7619-1/2011. Proprietăţile de tracţiune s-au măsurat cu ajutorul unui echipament de tracţiune de tip Schopper. Rezistenţa la rupere a fost determinată pe epruvete în formă de halteră conform ISO 37/2012. Rezistenţa la sfâşiere s-a măsurat în conformitate cu SR EN 12771/2003, folosind epruvete 
EN 12771/2003 using angular test pieces (type II). Test

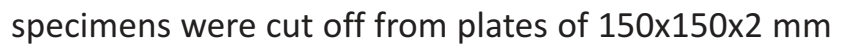
by means of an automatic punching die. Curing characteristics were determined by an oscillating disk rheometer (Monsanto), at $160^{\circ} \mathrm{C}$ for 30 minutes, according to the SR ISO 3417/1997.

\section{Statistical Processing}

Statistical processing of data was performed in the SPSS version 13. It is aimed at explaining the relationship between the resulting variable (analyzed blend characteristic) and causal independent variable - absorbed dose, based on a mathematical relation known as regression model. Statistical models are applied to enable predictions of the future states based on information resulting from the previous states. They deal certainly with a prediction based on probably statistical elements, accompanied by some risks assumed previously to this prediction process [12-15].

Selection of adequate factorial regression models and testing their validity are carried out in several stages, as follows:

- Stage 1. Plotting the relationship between the effect variable and independent variable by means of point cloud. Based on such plots the suggested functions revealing the relationship in the best way were selected.

- Stage 2. Application of ANOVA dispersion analysis test to test the model validity. Such a test involves the calculation of the following variation types:

$$
\sum_{i=1}^{n}\left(y_{i}-\bar{y}\right)
$$

which means the total variance and is marked SST;

$$
\sum_{i=1}^{n}\left(y_{i}-\hat{y}_{i}\right)^{2}
$$

which means the residual variance and is marked SSE;

$$
\sum_{i=1}^{n}\left(\hat{y}_{i}-\bar{y}\right)
$$

which means the variance explained based on the regression and is marked SSR, where: $y_{i}=$ experimental values; $\underline{y}_{i}=$ values adjusted based on the regression model; $y=$ the mean of the experimental values. de testare unghiulare (de tip II). S-au tăiat specimene de analiză din plăci de 150x150×2 mm, cu ajutorul unei ştanţe automate. Caracteristicile de vulcanizare au fost determinate cu ajutorul unui reometru cu disc oscilant (Monsanto), la $160^{\circ} \mathrm{C}$ timp de 30 minute, conform SR ISO 3417/1997.

\section{Prelucrarea statistică}

Prelucrarea statistică a datelor experimentale s-a realizat în SPSS versiunea 13. Aceasta are scopul de a explica relaţia dintre variabila rezultată (caracteristica amestecului analizat) şi variabila independentă de cauzalitate - doza absorbită, pe baza unui raport matematic cunoscut sub numele de model de regresie. Modelele statistice sunt aplicate pentru a face predicţii ale viitoarelor condiţii pe baza informaţiilor rezultate din condiţiile anterioare. Tratează cu certitudine predicţiile bazate pe elemente de probabilitate statistică, însoţite de o serie de riscuri asumate anterior în acest proces de predicţie [12-15].

Alegerea unui model de regresie unifactorială adecvat şi testarea validităţii acestuia presupune parcurgerea următoarelor etape:

- Etapa 1. Reprezentarea grafică a legăturii dintre variabila dependentă şi independentă prin intermediul norului de puncte. Pe baza acestuia se vor alege funcţiile sugerate care redau cel mai bine legătura.

- Etapa 2. Utilizarea testului de analiză dispersională ANOVA pentru testarea validităţii modelului. Un asemenea test presupune calcularea următoarelor tipuri de variaţie:

care reprezintă variaţia totală şi este notată cu SST;

care reprezintă variaţia reziduală şi este notată cu SSE;

care reprezintă variaţia explicată pe baza regresiei şi este notată cu SSR, unde: $y_{i}=$ valori experimentale; $y_{i}=$ valori ajustate pe baza modelului de regresie; $y=$ media valorilor experimentale. 
If the variation explained by the observed value spreading due to the factorial variable, according to the analyzed regression model, is larger than the spreading of the same values due to chance, the model is considered to be valid. To test this statistic assumption the Fischer ratio was used, calculated using the relation below.
Dacă variaţia explicată prin împrăştierea valorilor observate datorată variabilei factoriale, conform modelului de regresie analizat, este mai mare decât împrăştierea aceloraşi valori datorate întâmplării se consideră că modelul este valid. Pentru a testa această ipoteză statistică, s-a utilizat raportul Fischer calculat cu ajutorul relaţiei de mai jos.

$$
F_{\text {calc }}=\frac{\sum_{i=1}^{n}\left(\hat{y}_{i}-\bar{y}\right)}{k} / \frac{\sum_{i=1}^{n}\left(y_{i}-\hat{y}_{i}\right)^{2}}{n-k-1}
$$

where $k$ is the number of factorial variables in the model and $n$ is the number of observations.

If the plot suggested several regression functions, the test of the dispersion analysis was performed for each of them, and the models where the value of $F$ ratio between the variation explained by spreading of values due to the factorial variable and variation due to randomness has no statistical significance were discarded.

- Stage 3. Testing the significance of the regression model parameters. Judging a model as valid based only on the dispersion analysis test is not conclusive. Every regression model parameter has to have a statistic significance for a probability of at least 0.95 . Tests for parameter significance were performed by means of the Student test (Relation 5), considering a trial number less than 30.

unde $k$ este numărul de variabile factoriale din model, iar $n$ este numărul de observaţii.

În cazul în care reprezentarea grafică sugerează mai multe funç̧ii de regresie, se va efectua testul de analiză dispersională pentru fiecare şi se va renunţa la modelele pentru care valoarea raportului $\mathrm{F}$ dintre variaţia explicată prin împrăştierea valorilor observate datorată variabilei factoriale şi variaţia datorată întâmplării nu are semnificaţie statistică.

- Etapa 3. Testarea semnificaţie parametrilor modelului de regresie. Nu este concludent să diagnosticăm un model ca valid doar pe baza testului de analiză dispersională. Este necesar ca fiecare parametru al modelului de regresie să aibă semnificaţie statistică pentru o probabilitate de cel puţin 0,95. Testele pentru semnificaţia parametrilor au fost efectuate prin intermediul testului Student (relaţia 5), luând în considerare un număr de încercări mai mic de 30.

$$
t_{\text {calc }}=\frac{b_{i}-\beta_{i}}{s_{b_{i}}}
$$

where: $\beta_{i}$ is the parameter $i$ of the single factor regression model (if, assuming that it has no statistic significance, it is 0$) ; b_{i}$ is the parameter $i$ estimator for the regression model obtained from the experimental data; $s_{b i}=$ standard deviation of the $b_{i}$ estimator. During the experimental data analysis the models with parameters of no statistic significance have been discarded.

- Stage 4. Computing the determination coefficient $R^{2}$ : This means to find out the ratio of the variation given by the regression model to the total variation of the effect variable being analyzed. unde: $\beta_{i}$ este parametrul $i$ al modelului de regresie unifactorial (în cazul în care, presupunând că nu are nicio semnificaţie statistică, este 0 ); $b_{i}$ este estimatorul parametrului $i$ pentru modelul de regresie obţinut din datele experimentale; $s_{b i}=$ abaterea standard a estimatorului $b_{i}$. Se va renunţa la acele modele care au parametri fără semnificaţie statistică.

- Etapa 4. Determinarea coeficientului de determinaţie R2. Acesta arată proporţia variaţiei explicate de modelul de regresie în variaţia totală a variabilei dependente analizate.

$$
R^{2}=\sum_{i=1}^{n}\left(\hat{y}_{i}-\bar{y}\right) / \sum_{i=1}^{n}\left(y_{i}-\bar{y}\right)
$$


If several regression models were validated during the previous stages, the model with the highest determination coefficient $\left(R^{2}\right)$ value is to be selected.

- Stage 5. Assessing the values of the analyzed characteristics. The values of the analyzed characteristics for various irradiation doses were estimated based on every validated regression model. The obtained values have fallen in the confidence intervals presumably guaranteed (based on the relation 7):
În cazul în care, parcurgând etapele anterioare, am validat mai multe modele de regresie, se va alege acela pentru care valoarea $R^{2}$ este mai mare.

- Etapa 5. Estimarea valorilor caracteristicilor analizate. Valorile caracteristicilor analizate pentru diferite doze de iradiere au fost estimate pe baza fiecărui model de regresie validat. Valorile obţinute sau încadrat în intervalele de încredere probabil garantate (pe baza relaţiei 7).

$$
\hat{y}_{D}-t_{\alpha / 2 ; n-k-1} \times s_{\hat{y}_{D}} \leq y_{D} \leq \hat{y}_{D}+t_{\alpha / 2 ; n-k-1} \times s_{\hat{y}_{D}}
$$

where $\hat{y}_{D}$ is the estimated value of the characteristic based on the regression model for a given irradiation level D, $s_{\hat{y}_{D}}$ is the standard value calculated from the relation $8, t_{\alpha / 2 ; n-k-1}$ is the value calculated for the Student distribution based on the safety level $\alpha$ (it was assumed to be 0.05 as the result guarantee with $95 \%$ probability was intended), and $d f=n-k-1$ is the number of freedom degrees where $n$ is the number of observations and $k$ is the number of causal variables (there is a single independent variable here: irradiation dose). unde $\hat{y}_{D}$ este valoarea estimată a caracteristicii pe baza modelului de regresie pentru o doză de iradiere dată, D, $s_{\hat{y}_{D}}$ este valoarea standard calculată din relaţia $8, t_{\alpha / 2 ; n-k-1}$ este valoarea calculată pentru distribuţia Student pe baza nivelului de siguranţă $\alpha$ (s-a presupus a fi 0,05 deoarece s-a urmărit garantarea rezultatului cu probabilitate de $95 \%$ ) şi $d f=n-k-1$ este numărul de grade de libertate unde $n$ este numărul de observaţii şi $k$ este numărul de variabile cauzale (există o singură variabilă independentă: doza de iradiere).

$$
s_{\hat{y}_{D}}=\sqrt{\frac{S S E}{n-k-1}\left[1+\frac{1}{n}+\frac{(D-\bar{D})^{2}}{\sum_{i}^{n}\left(D_{i}-\bar{D}\right)^{2}}\right]}
$$

where $\bar{D}$ is the irradiation mean dose and $\sum_{i}^{n}\left(D_{i}-\bar{D}\right)^{2}$ is the total variation of the independent variabie (irradiation dose).

\section{RESULTS AND DISCUSSIONS}

The physico-mechanical characteristics of blends based on EVA and TAC crosslinked with peroxides are taken as reference values and are presented in Table 1. unde $\bar{D}$ este doza medie de iradiere şi $\sum_{i}^{n}\left(D_{i}-\bar{D}\right)^{2}$ este variaţia totală a variabilei independente (doza de iradiere).

\section{REZULTATE ŞI DISCUTII}

Caracteristicile fizico-mecanice ale amestecurilor pe bază de EVA şi TAC, reticulate cu ajutorul peroxizilor, sunt considerate valori de referinţă şi sunt prezentate în Tabelul 1. 
Table 1: Reference characteristics

Tabelul 1: Caracteristici de referinţă

\begin{tabular}{|c|c|c|c|}
\hline $\begin{array}{l}\text { Blend characteristics } \\
\text { Caracteristici amestec }\end{array}$ & $\begin{array}{l}\text { Sample } 1 \\
\text { Proba } 1\end{array}$ & $\begin{array}{l}\text { Sample } 2 \\
\text { Proba } 2\end{array}$ & $\begin{array}{l}\text { Average values } \\
\text { Valori medii }\end{array}$ \\
\hline $\begin{array}{l}\text { Hardness, }{ }^{\circ} \mathrm{ShA} \\
\text { Duritate, }{ }^{\circ} \mathrm{Sh} A\end{array}$ & 81 & 83 & 82 \\
\hline $\begin{array}{c}100 \% \text { modulus, } \mathrm{N} / \mathrm{mm}^{2} \\
\text { Modul } 100 \%, \mathrm{~N} / \mathrm{mm}^{2}\end{array}$ & 3.8 & 4.1 & 3.95 \\
\hline $\begin{array}{c}\text { Tensile strength, } \mathrm{N} / \mathrm{mm}^{2} \\
\text { Rezistenţa la rupere, } \mathrm{N} / \mathrm{mm}^{2}\end{array}$ & 6.4 & 6.2 & 6.3 \\
\hline $\begin{array}{l}\text { Elongation at break, } \% \\
\text { Alungirea la rupere, } \%\end{array}$ & 200 & 200 & 200 \\
\hline $\begin{array}{l}\text { Residual elongation, \% } \\
\text { Alungire remanentă, \% }\end{array}$ & 53 & 46 & 49.5 \\
\hline $\begin{array}{c}\text { Tear strength, } \mathrm{N} / \mathrm{mm} \\
\text { Rezistenţa la sfâşiere, } \mathrm{N} / \mathrm{mm}\end{array}$ & 49 & 30.5 & 39.75 \\
\hline
\end{tabular}

Within the analysis of experimental data, a distinct analysis was performed for each characteristic, attempting to validate a model to synthesize the way in which these characteristics change depending on the intensity of electron beam irradiation.

Hardness of EVA and TAC blends crosslinked and grafted by means of electron beam against the irradiation dose is presented in Figure 1. Experimental value spreading has suggested a relationship as a second degree curve between the two variables. Equation for the validated regression model is the following:
În analiza datelor experimentale s-a efectuat o analiză distinctă pentru fiecare caracteristică încercând să se valideze un model care să sintetizeze modul în care aceste caracteristici se modifică în funcţie de intensitatea iradierii cu electroni acceleraţi.

Duritatea amestecurilor pe bază de EVA şi TAC reticulate şi grefate cu ajutorul electronilor acceleraţi în funcţie de doza de iradiere este prezentată în Figura 1. Împrăştierea valorilor experimentale sugerează că între cele două variabile există o legătură sub forma unei parabole de gradul 2. Ecuaţia pentru modelul de regresie validat este:

$$
y_{\left(x_{i}\right)}=81,853+0,530 \cdot x_{i}-0,024 \cdot x_{i}^{2}
$$

The value of the determination coefficient $\left(R^{2}\right)$ is 0.258 , suggesting that the regression model has explained $25.8 \%$ of this characteristic variation. According to this model, the blend hardness has increased by sample irradiation, reaching a maximum value of $84.76^{\circ} \mathrm{ShA}$ corresponding to an irradiation of $11.04 \mathrm{Mrad}$, and afterwards the characteristic value has decreased. To obtain the best value for the characteristic, close to $82^{\circ} \mathrm{ShA}$ obtained by crosslinking with peroxides, the blend is recommended to be irradiated with electron beam of 8-15 Mrad.
Valoarea coeficientului de determinaţie $R^{2}$ este 0,258 , sugerând că modelul de regresie explică $25,8 \%$ din variaţia acestei caracteristici. Conform acestui model, prin procedura de iradiere a probelor se obţine o creştere a durităţii amestecului, atingându-se o valoare maximă de $84,76^{\circ} \mathrm{ShA}$ corespunzătoare unei iradieri de 11,04 Mrad, după care valoarea caracteristicii scade. Pentru a obţine valori optime ale caracteristicii, comparabile cu cea de $82^{\circ} \mathrm{ShA}$, obţinută prin metoda de reticulare cu ajutorul peroxizilor, se recomandă să se realizeze o iradiere a amestecului cu electroni acceleraţi la o intensitate în intervalul 8-15 Mrad. 


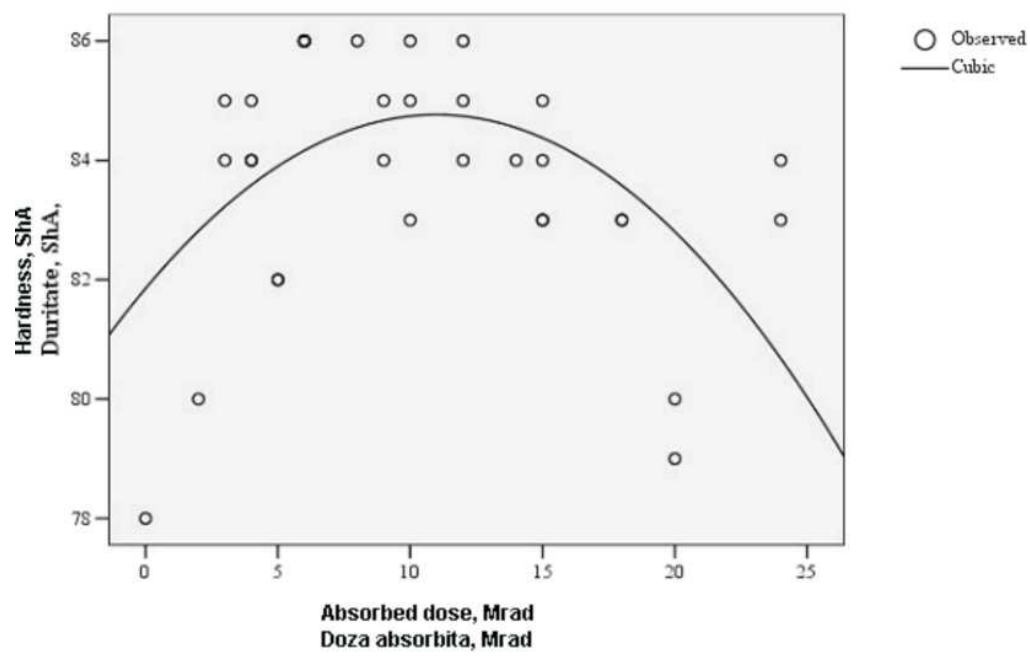

Figure 1. Hardness of blends based on EVA and TAC depending on irradiation intensity

Figura 1. Duritatea amestecurilor pe bază de EVA şi TAC în funcţie de intensitatea iradierii

Tensile strength for the EVA and TAC blends crosslinked and grafted by means of the accelerated electron beam against the irradiation dose is presented in Figure 2. The experimental value spreading has suggested a relationship as a parable of grade 3 between the two variables. As a result of performing the dispersion analysis test, a value of Fischer ratio of 240,901 was obtained, which makes us state with a probability close to unity that the variance explained by the model is significantly higher than the residual variance. Equation for the validated regression model is the following:
Rezistenţa la rupere a amestecurilor pe bază de EVA şi TAC reticulate şi grefate cu ajutorul electronilor acceleraţi în funcţie de intensitatea radiaţiilor este prezentată în Figura 2. Împrăştierea valorilor experimentale sugerează că între cele două variabile există o legătură sub forma unei parabole de gradul 3. în urma efectuării testului de analiză dispersională s-a obţinut o valoare a raportului Fischer de 240,901, ceea ce ne determină să afirmăm cu o probabilitate apropiată de unitate că variaţia explicată de model este semnificativ statistic mai mare decât variaţia reziduală. Ecuaţia pentru modelul de regresie validat este următoarea:

$$
y_{\left(x_{i}\right)}=3,728 \cdot x_{i}-0,312 \cdot x_{i}^{2}+0,007 \cdot x_{i}^{3}
$$

The initial tensile strength value increases with increasing radiation intensity, reaching a maximum of $13.5 \mathrm{~N} / \mathrm{mm}^{2}$ for $8 \mathrm{Mrad}$ irradiation intensity, then decreases. The values 6 btained are up to $215 \%$ higher than those obtained in crosslinking using peroxides. It is recommended that the mixture be subjected to electron beam irradiation with doses in the range of 6$10 \mathrm{Mrad}$ in order to obtain the maximum values for this feature.
Valoarea rezistenţei la rupere iniţial creşte odată cu creşterea intensităţii radiaţiilor atingând o valoare maximă de $13,5 \mathrm{~N} / \mathrm{mm}^{2}$ pentru o intensitate a iradierii de $8 \mathrm{Mrad}$, după care scade. Valorile obţinute sunt de până la 215\% mai mari decât cele obţinute în reticularea cu peroxizi. Se recomandă ca amestecul să fie supus unei iradieri cu electroni acceleraţi cu doze cuprinse între 6-10 Mrad pentru a putea obţine valori maxime ale acestei caracteristici. 


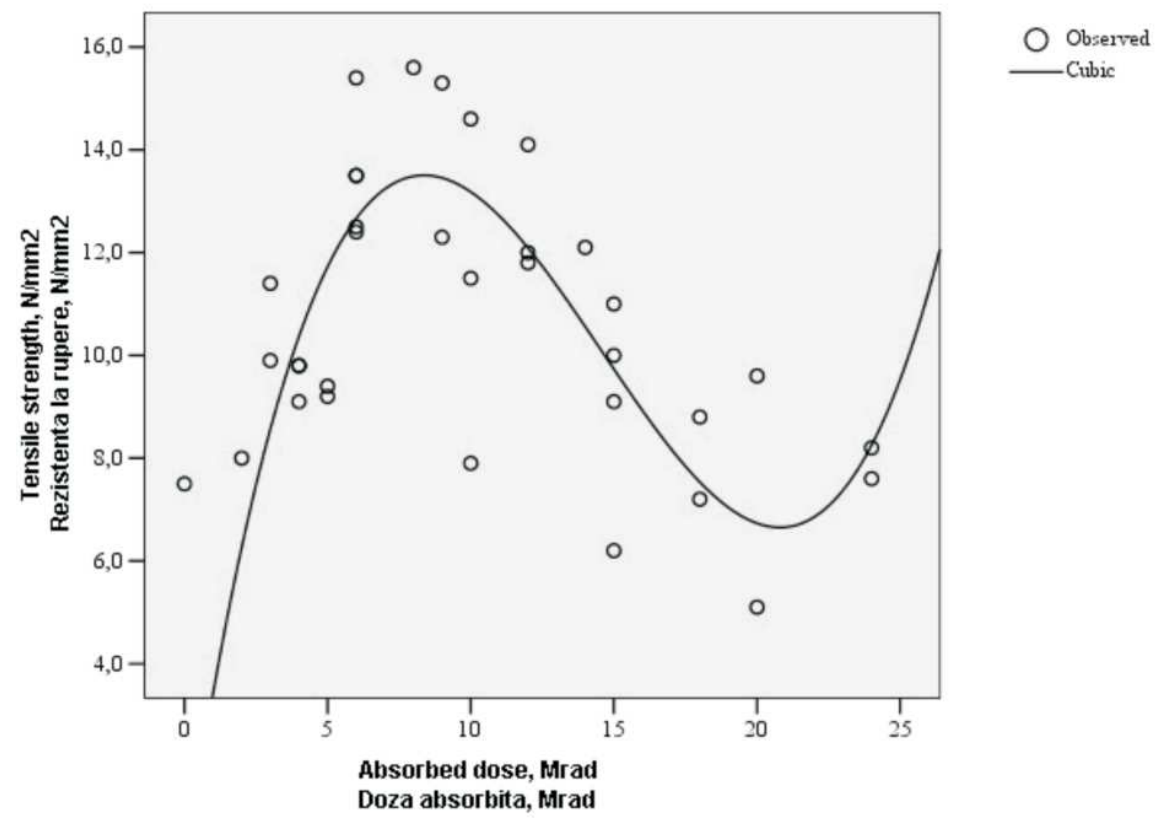

Figure 2. Tensile strength of blends based on EVA and TAC depending on irradiation dose

Figura 2. Rezistenţa la rupere a amestecurilor pe bază de EVA şi TAC în funcţie de doza de iradiere

Elongation at break of blends based on EVA and TAC crosslinked and grafted with electron beam depending on the intensity of radiation is presented in Figure 3. Spreading of experimental values suggests that there is an exponential relationship between the two variables. As the calculated value of $F$ ratio is 101.61 and the significance level is close to 0 , we can state with a probability close to unity that the created model is valid. The validated model is given by the following relationship:
Alungirea la rupere a amestecurilor pe bază de EVA şi TAC reticulate şi grefate cu ajutorul electronilor acceleraţi în funç̧ie de intensitatea radiaţiilor este prezentată în Figura 3. Împrăştierea valorilor experimentale sugerează că între cele două variabile există o legătură de forma unei exponenţiale. Deoarece valoarea calculată a raportului $F$ este 101,61 iar nivelul de semnificaţie este aproape de 0 , putem afirma cu o probabilitate apropiată de unitate că modelul construit este valid. Modelul validat este dat de următoarea relaţie:

$$
y_{\left(x_{i}\right)}=608.625 \cdot x_{i}^{(-0,045)}
$$

The relationship between electron beam irradiation intensity and elongation at break is very strong (correlation ratio is 0.872 ) and the variance explained by the analyzed regression model accounts for $76 \%$ of total variance of the analyzed characteristic.

The residual elongation of blends based on EVA and TAC crosslinked and grafted by means of electron beam depending on the irradiation dose is shown in Figure 4. Spreading of experimental values 3uggests that there is an exponential relationship between the two variables. Interpreting analysis of variance test results, we conclude that the characteristic variation explained by the regression model is significantly
Legătura dintre intensitatea iradierii cu electroni acceleraţi şi alungirea la rupere este foarte puternică (raportul de corelaţie este 0,872 ), iar variaţia explicată prin modelul de regresie analizat explică $76 \%$ din variaţia totală a caracteristicii analizate.

Alungirea remanentă a amestecurilor pe bază de EVA şi TAC reticulate şi grefate cu ajutorul electronilor acceleraţi în funcţie de doza de iradiere este prezentată în Figura 4. Împrăştierea valorilor experimentale sugerează că între cele două variabile există o legătură de formă exponenţială. Interpretând rezultatele testului de analiză dispersională, putem concluziona că variaţia caracteristicii explicată prin modelul de regresie este semnificativ statistic mai mare decât 
higher than the residual variance. We can guarantee this assertion with a probability close to unity. The model explains $75.1 \%$ of the variation analysis $\left(R^{2}=0.751\right)$ and is given by the following equation: variaţia reziduală. Putem garanta această afirmaţie cu o probabilitate apropiată de unitate. Modelul explică $75,1 \%$ din variaţia variabilei analizate $\left(R^{2}=0,751\right)$ şi este dat de următoarea ecuaţie:

$$
y_{\left(x_{i}\right)}=347,839 \cdot x_{i}^{(-0,077)}
$$

As we seek to get blends with the lowest residual elongation by crosslinking, it is recommended to use an irradiation intensity as high as possible.
Deoarece căutăm ca, prin reticulare, să obţinem amestecuri cu o alungire remanentă cât mai scăzută, se recomandă să se utilizeze o intensitate a iradierii cât mai mare.

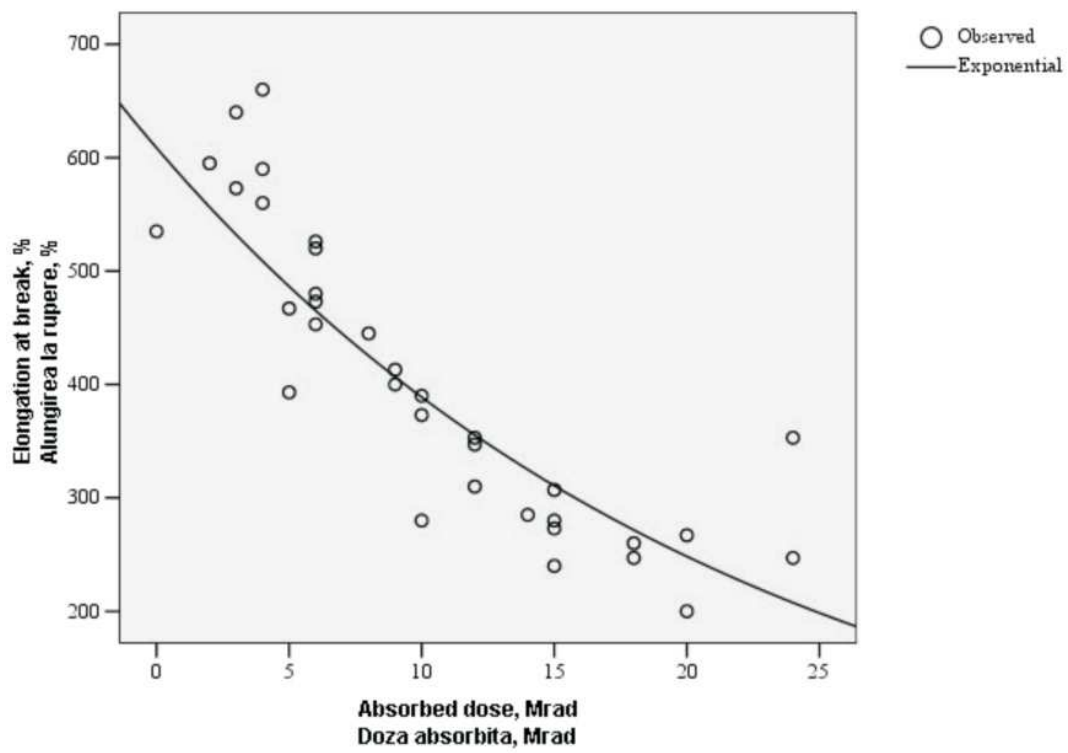

Figure 3. Elongation at break of blends based on EVA and TAC depending on irradiation intensity Figura 3. Alungirea la rupere a amestecurilor pe bază de EVA şi TAC în funcţie de intensitatea iradierii

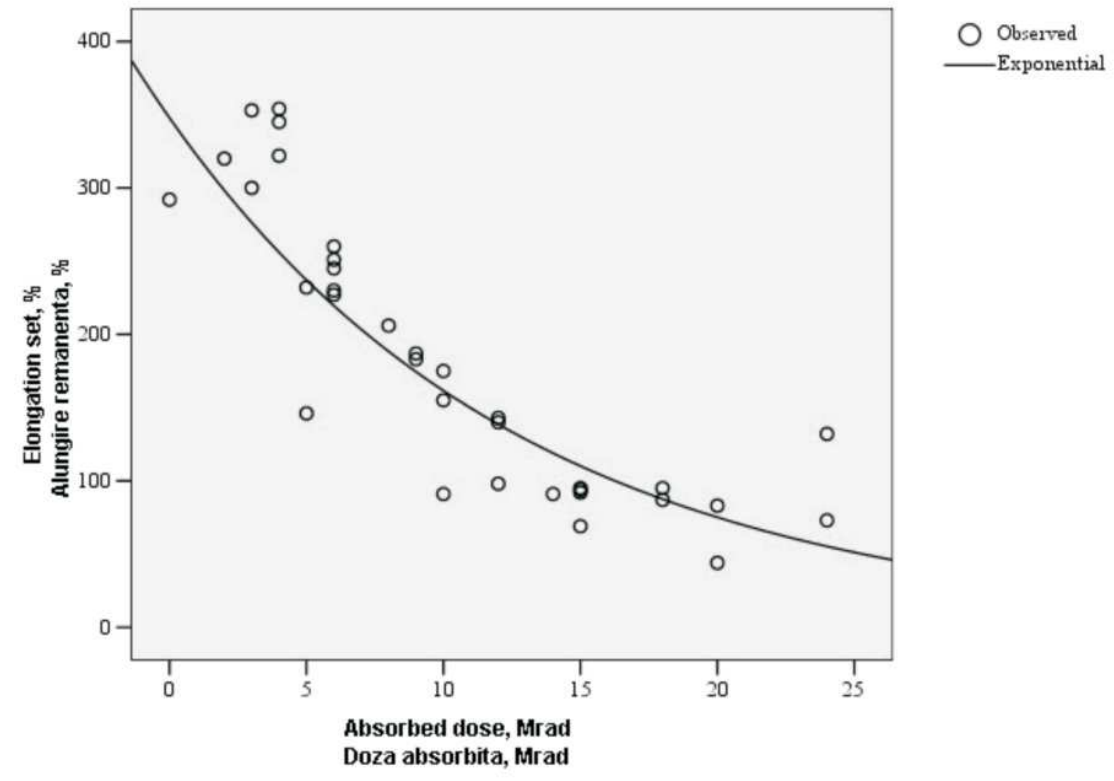

Figure 4. Residual elongation of blends based on EVA and TAC depending on irradiation intensity Figura 4. Alungirea remanentă a amestecurilor pe bază de EVA şi TAC în funcţie de intensitatea iradierii 
Tear strength of blends based on EVA and TAC crosslinked and grafted by electron beam depending on irradiation intensity is presented in Figure 5 . Spreading of experimental values suggests that there is a reverse exponential relationship between the two variables. As the calculated value of the $F$ ratio is 56.537 , and the significance level is close to 0 , we can state with a probability close to unity that the created model is valid.
Rezistenţa la sfâşiere a amestecurilor pe bază de EVA şi TAC reticulate şi grefate cu ajutorul electronilor acceleraţi în funcţie de intensitatea radiaţiilor este prezentată în Figura 5. Împrăştierea valorilor experimentale sugerează că între cele două variabile există o legătură inversă de formă exponenţială. Deoarece valoarea calculată a raportului F este 56,537, iar nivelul de semnificaţie este aproape de 0, putem afirma cu o probabilitate apropiată de unitate că modelul construit este valid.

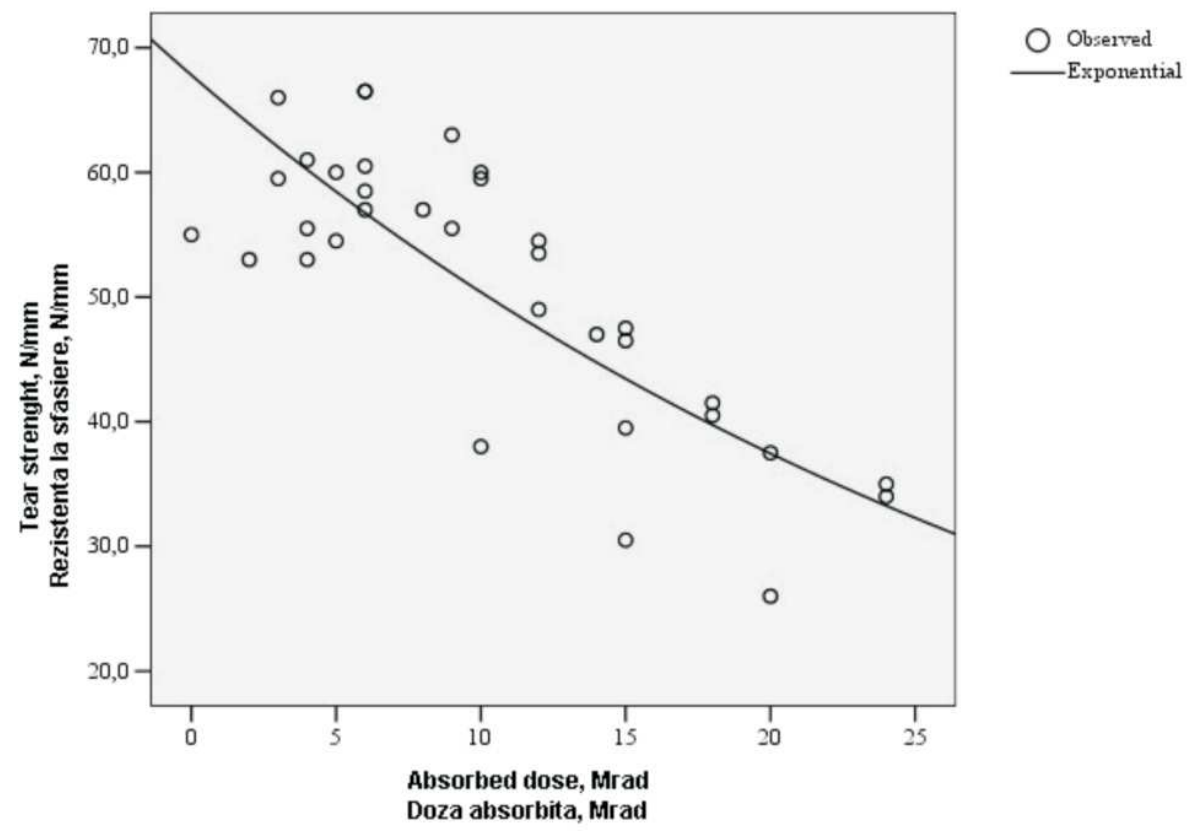

Figure 5. Tear strength of blends based on EVA and TAC depending on irradiation intensity

Figura 5. Rezistenţa la sfâşiere a amestecurilor pe bază de EVA şi TAC în funcţie de intensitatea iradierii

Based on results of Student test, it can be stated that the model is validated and has the following relation:
Pe baza rezultatelor testului Student se poate afirma că modelul este validat şi are următoarea relaţie:

$$
y_{\left(x_{i}\right)}=67,812 \cdot x_{i}^{(-0,03)}
$$

The regression model explains $63.9 \%$ of the analyzed characteristic variation. Tear resistance value decreases with increasing radiation intensity. It is recommended that the mixture not be subjected to electron beam irradiation above $10 \mathrm{Mrad}$ in order to obtain values $\mathrm{df}$ this characteristic comparable to those of samples crosslinked with peroxides.

$100 \%$ modulus of the blends based on EVA and TAC crosslinked and grafted by means of electron beam depending on the intensity of the radiation is shown in
Modelul de regresie explică $63,9 \%$ din variaţia caracteristicii analizate. Valoarea rezistenţei la sfâşiere scade odată cu creşterea intensităţii radiaţiilor. Se recomandă ca amestecul să nu fie supus unei iradieri cu electroni acceleraţi mai mare de $10 \mathrm{Mrad}$ pentru a putea obţine valori ale acestei caracteristici comparabile cu cele ale probelor reticulate cu ajutorul peroxizilor.

Modulul 100\% al amestecurilor pe bază de EVA şi TAC reticulate şi grefate $\mathrm{cu}$ ajutorul electronilor acceleraţi în funcţie de intensitatea radiaţiilor este 
Figure 6. Spreading of experimental values 3uggests that the two variables are linked by a 2 nd degree parabola relationship. Estimated parameters based on the model used are significantly different from 0 , and variance explained by the model exceeds the residual variance (Fischer ratio value is 8.246 and the significance level is close to 0 ). The validated model is given by the following equation: prezentat în Figura 6. Împrăştierea valorilor experimentale sugerează că între cele două variabile există o legătură sub forma unei parabole de gradul 2 . Parametrii estimaţi pe baza modelului utilizat sunt semnificativ diferiţi de 0 , iar variaţia explicată de model o depăşeşte pe cea reziduală (valoarea raportului Fischer este 8,246, iar nivelul de semnificaţie aproape de 0). Modelul validat este dat de următoarea relaţie:

$$
y_{\left(x_{i}\right)}=3,191+0,086 \cdot x_{i}-0,003 \cdot x_{i}^{2}
$$

The value of $R^{2}$ indicates that the variation according to the model explains $34.7 \%$ of spreading of this variable.

$300 \%$ modulus of the blends based on EVA and TAC crosslinked and grafted using electron beam depending on irradiation intensity is shown in Figure 7. Spreading of experimental values suggests that the two variables are linked by a reverse linear function relationship. Estimated parameters based on the linear model are significantly different from 0 , and variance explained by the model exceeds the residual variance (Fischer ratio value is 99.614 and the significance level is close to 0 ). The validated model is given by the following equation:
Valoarea lui $\mathrm{R}^{2}$ arată că variaţia conform modelului explică $34,7 \%$ din împrăştierea acestei variabile.

Modulul 300\% al amestecurilor pe bază de EVA şi TAC reticulate şi grefate $\mathrm{cu}$ ajutorul electronilor acceleraţi în funcţie de intensitatea radiaţiilor este prezentat în Figura 7. Împrăştierea valorilor experimentale sugerează că între cele două variabile există o legătură sub forma unei funcţii liniare inverse. Parametrii estimaţi pe baza modelului liniar sunt semnificativ diferiţi de 0 , iar variaţia explicată de model o depăşeşte pe cea reziduală (valoarea raportului Fischer este 99,614 iar nivelul de semnificaţie aproape de 0). Modelul validat este dat de următoarea relaţie:

$$
y_{\left(x_{i}\right)}=2,784+0,594 \cdot x_{i}
$$

The value of $R^{2}$ indicates that the variation according to the model explains $85.4 \%$ of spreading of this variable. There is a very strong direct relationship between the two variables (correlation ratio is 0.924 ).
Valoarea lui $R^{2}$ arată cu variaţia conform modelului explică $85,4 \%$ din împrăştierea acestei variabile. Între cele două variabile există o legătură foarte puternică directă (raportul de corelaţie este 0,924 ). 


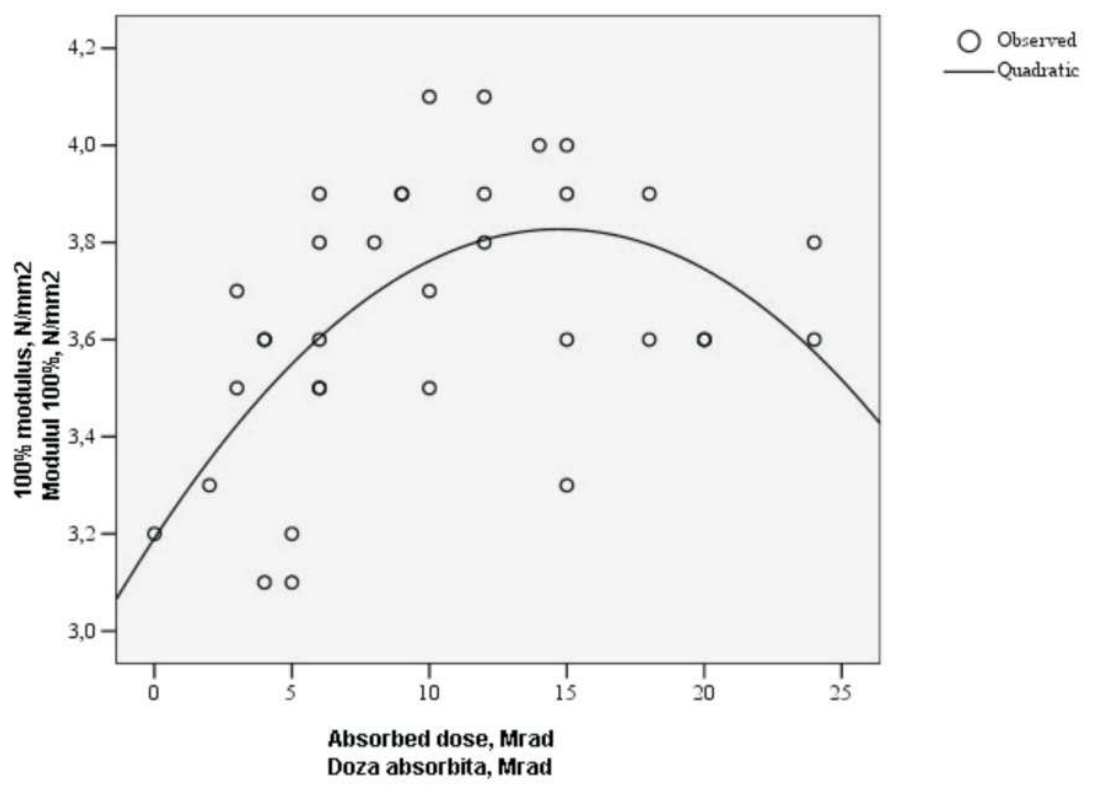

Figure $6.100 \%$ modulus of blends based on EVA and TAC depending on irradiation intensity Figura 6. Modulul 100\% al amestecurilor pe bază de EVA şi TAC în funcţie de intensitatea iradierii

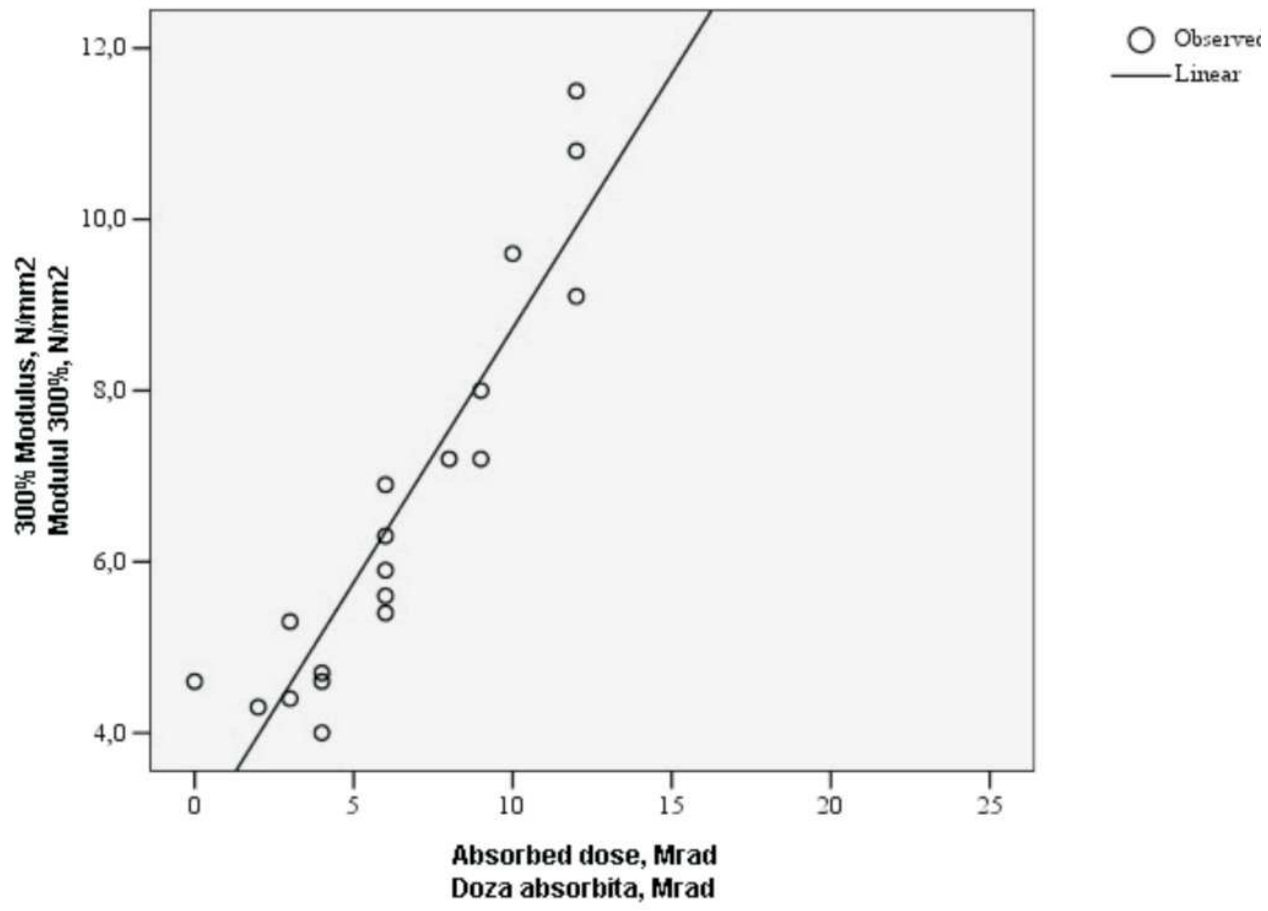

Figure 7. $300 \%$ modulus of blends based on EVA and TAC depending on irradiation intensity Figura 7. Modulul $300 \%$ al amestecurilor pe bază de EVA şi TAC în funcţie de intensitatea iradierii

Once the regression models are validated, characteristics of blends for various irradiation dose values can be estimated. They are presented in Tables 2-6.
Odată validate modelele de regresie, se pot estima caracteristicile amestecurilor pentru diferite valori ale dozei de iradiere. Acestea sunt prezentate în Tabelele 2-6. 
Table 2: Estimation of blend characteristics for 6 Mrad

Tabelul 2: Estimarea caracteristicilor amestecului pentru 6 Mrad

\begin{tabular}{|c|c|c|c|c|c|}
\hline \multirow{2}{*}{$\begin{array}{l}\text { Characteristic } \\
\text { Caracteristică }\end{array}$} & \multirow{2}{*}{$\begin{array}{l}\text { Estimated value } \\
\text { Valoare estimată }\end{array}$} & \multirow{2}{*}{$t_{\alpha / 2, d f}^{*}$} & \multirow{2}{*}{$\begin{array}{l}\text { Limit of error } \\
\text { Eroare limită }\end{array}$} & \multicolumn{2}{|c|}{$\begin{array}{l}\text { Confidence interval } \\
\text { Interval de încredere }\end{array}$} \\
\hline & & & & $\begin{array}{l}\text { Lower limit } \\
\text { Limita inferioară }\end{array}$ & $\begin{array}{l}\text { Upper limit } \\
\text { Limita superioară }\end{array}$ \\
\hline $\begin{array}{l}\text { Hardness, ShA } \\
\text { Duritate, ShA }\end{array}$ & 84.17 & 2.03 & 3.84 & 80.32 & 88.01 \\
\hline $\begin{array}{l}100 \% \text { modulus, } \mathrm{N} / \mathrm{mm}^{2} \\
\text { Modul } 100 \%, \mathrm{~N} / \mathrm{mm}^{2}\end{array}$ & 3.60 & 2.03 & 0.47 & 3.13 & 4.07 \\
\hline $\begin{array}{l}300 \% \text { modulus, } \mathrm{N} / \mathrm{mm}^{2} \\
\text { Modul } 300 \%, \mathrm{~N} / \mathrm{mm}^{2}\end{array}$ & 6.35 & 2.10 & 0.61 & 5.74 & 6.95 \\
\hline $\begin{array}{l}\text { Tensile strength, } \mathrm{N} / \mathrm{mm}^{2} \\
\text { Rezistenţa la rupere, } \mathrm{N} / \mathrm{mm}^{2}\end{array}$ & 12.65 & 2.03 & 4.83 & 7.82 & 17.48 \\
\hline $\begin{array}{l}\text { Elongation at break, } \% \\
\text { Alungirea la rupere, } \%\end{array}$ & 561.48 & 2.03 & 0.34 & 561.14 & 561.82 \\
\hline $\begin{array}{l}\text { Residual elongation, \% } \\
\text { Alungire remanentă, \% }\end{array}$ & 303.01 & 2.03 & 0.59 & 302.42 & 303.61 \\
\hline $\begin{array}{c}\text { Tear strength, } \mathrm{N} / \mathrm{mm} \\
\text { Rezistenţă la sfâşiere, } \mathrm{N} / \mathrm{mm}\end{array}$ & 64.26 & 2.03 & 0.30 & 63.96 & 64.56 \\
\hline
\end{tabular}

* df is the number of degrees of freedom corresponding to the residual variance taken from the corresponding ANOVA table

*df reprezintă numărul de grade de libertate corespunzător variaţiei reziduale preluat din tabelul ANOVA corespunzător

Table 3: Estimation of blend characteristics for $8 \mathrm{Mrad}$

Tabelul 3: Estimarea caracteristicilor amestecului pentru 8 Mrad

\begin{tabular}{|c|c|c|c|c|c|}
\hline \multirow{2}{*}{$\begin{array}{l}\text { Characteristic } \\
\text { Caracteristică }\end{array}$} & \multirow{2}{*}{$\begin{array}{l}\text { Estimated value } \\
\text { Valoare estimată }\end{array}$} & \multirow{2}{*}{$t_{\alpha / 2, d f}^{*}$} & \multirow{2}{*}{$\begin{array}{l}\text { Limit of error } \\
\text { Eroare limită }\end{array}$} & \multicolumn{2}{|c|}{$\begin{array}{l}\text { Confidence interval } \\
\text { Interval de încredere }\end{array}$} \\
\hline & & & & $\begin{array}{l}\text { Lower limit } \\
\text { Limita inferioară }\end{array}$ & $\begin{array}{l}\text { Upper limit } \\
\text { Limita superioară }\end{array}$ \\
\hline $\begin{array}{l}\text { Hardness, ShA } \\
\text { Duritate, ShA }\end{array}$ & 84.56 & 2.03 & 3.83 & 80.73 & 88.38 \\
\hline $\begin{array}{l}100 \% \text { modulus, } \mathrm{N} / \mathrm{mm}^{2} \\
\text { Modul } 100 \%, \mathrm{~N} / \mathrm{mm}^{2}\end{array}$ & 3.69 & 2.03 & 0.47 & 3.22 & 4.16 \\
\hline $\begin{array}{l}300 \% \text { modulus, } \mathrm{N} / \mathrm{mm}^{2} \\
\text { Modul } 300 \%, \mathrm{~N} / \mathrm{mm}^{2}\end{array}$ & 7.54 & 2.10 & 0.60 & 6.93 & 8.14 \\
\hline $\begin{array}{l}\text { Tensile strength, } \mathrm{N} / \mathrm{mm}^{2} \\
\text { Rezistenţa la rupere, } \mathrm{N} / \mathrm{mm}^{2}\end{array}$ & 13.44 & 2.03 & 4.81 & 8.63 & 18.25 \\
\hline $\begin{array}{l}\text { Elongation at break, } \% \\
\text { Alungirea la rupere, } \%\end{array}$ & 554.26 & 2.03 & 0.34 & 553.92 & 554.60 \\
\hline $\begin{array}{l}\text { Residual elongation, } \% \\
\text { Alungire remanentă, } \%\end{array}$ & 296.37 & 2.03 & 0.59 & 295.78 & 296.97 \\
\hline $\begin{array}{c}\text { Tear strength, } \mathrm{N} / \mathrm{mm} \\
\text { Rezistenţă la sfâşiere, } \mathrm{N} / \mathrm{mm}\end{array}$ & 63.71 & 2.03 & 0.30 & 63.41 & 64.01 \\
\hline
\end{tabular}

* df is the number of degrees of freedom corresponding to the residual variance taken from the corresponding ANOVA table

*df reprezintă numărul de grade de libertate corespunzător variaţiei reziduale preluat din tabelul ANOVA corespunzător 
Table 4: Estimation of blend characteristics for $10 \mathrm{Mrad}$

Tabelul 4: Estimarea caracteristicilor amestecului pentru $10 \mathrm{Mrad}$

\begin{tabular}{|c|c|c|c|c|c|}
\hline \multirow{2}{*}{$\begin{array}{l}\text { Characteristic } \\
\text { Caracteristică }\end{array}$} & \multirow{2}{*}{$\begin{array}{l}\text { Estimated value } \\
\text { Valoare estimată }\end{array}$} & \multirow{2}{*}{$\mathrm{t}_{\alpha / 2, \mathrm{df}}^{*}$} & \multirow{2}{*}{$\begin{array}{l}\text { Limit of error } \\
\text { Eroare limită }\end{array}$} & \multicolumn{2}{|c|}{$\begin{array}{l}\text { Confidence interval } \\
\text { Interval de încredere }\end{array}$} \\
\hline & & & & $\begin{array}{l}\text { Lower limit } \\
\text { Limita inferioară }\end{array}$ & $\begin{array}{l}\text { Upper limit } \\
\text { Limita superioară }\end{array}$ \\
\hline $\begin{array}{l}\text { Hardness, ShA } \\
\text { Duritate, ShA }\end{array}$ & 84.75 & 2.03 & 3.82 & 80.93 & 88.57 \\
\hline $\begin{array}{l}100 \% \text { modulus, } \mathrm{N} / \mathrm{mm}^{2} \\
\text { Modul } 100 \%, \mathrm{~N} / \mathrm{mm}^{2}\end{array}$ & 3.75 & 2.03 & 0.47 & 3.28 & 4.22 \\
\hline $\begin{array}{c}300 \% \text { modulus, } \mathrm{N} / \mathrm{mm}^{2} \\
\text { Modul } 300 \%, \mathrm{~N} / \mathrm{mm}^{2}\end{array}$ & 8.72 & 2.10 & 0.60 & 8.12 & 9.32 \\
\hline $\begin{array}{l}\text { Tensile strength, } \mathrm{N} / \mathrm{mm}^{2} \\
\text { Rezistenţa la rupere, } \mathrm{N} / \mathrm{mm}^{2}\end{array}$ & 13.08 & 2.03 & 4.80 & 8.28 & 17.88 \\
\hline $\begin{array}{l}\text { Elongation at break, } \% \\
\text { Alungirea la rupere, } \%\end{array}$ & 548.72 & 2.03 & 0.34 & 548.38 & 549.06 \\
\hline $\begin{array}{l}\text { Residual elongation, } \% \\
\text { Alungire remanentă, } \%\end{array}$ & 291.33 & 2.03 & 0.59 & 290.74 & 291.92 \\
\hline $\begin{array}{c}\text { Tear strength, } \mathrm{N} / \mathrm{mm} \\
\text { Rezistenţă la sfâşiere, } \mathrm{N} / \mathrm{mm}\end{array}$ & 63.29 & 2.03 & 0.30 & 62.99 & 63.58 \\
\hline
\end{tabular}

* df is the number of degrees of freedom corresponding to the residual variance taken from the corresponding ANOVA table *df reprezintă numărul de grade de libertate corespunzător variaţiei reziduale preluat din tabelul ANOVA corespunzător

Table 5: Estimation of blend characteristics for $12 \mathrm{Mrad}$

Tabelul 5: Estimarea caracteristicilor amestecului pentru $12 \mathrm{Mrad}$

\begin{tabular}{|c|c|c|c|c|c|}
\hline \multirow{2}{*}{$\begin{array}{l}\text { Characteristic } \\
\text { Caracteristică }\end{array}$} & \multirow{2}{*}{$\begin{array}{l}\text { Estimated value } \\
\text { Valoare estimată }\end{array}$} & \multirow{2}{*}{$t_{\alpha / 2, d f}^{*}$} & \multirow{2}{*}{$\begin{array}{l}\text { Limit of error } \\
\text { Eroare limită }\end{array}$} & \multicolumn{2}{|c|}{$\begin{array}{l}\text { Confidence interval } \\
\text { Interval de încredere }\end{array}$} \\
\hline & & & & $\begin{array}{l}\text { Lower limit } \\
\text { Limita inferioară }\end{array}$ & $\begin{array}{c}\text { Upper limit } \\
\text { Limita superioară }\end{array}$ \\
\hline $\begin{array}{l}\text { Hardness, ShA } \\
\text { Duritate, ShA }\end{array}$ & 84.76 & 2.03 & 3.82 & 80.93 & 88.58 \\
\hline $\begin{array}{l}100 \% \text { modulus, } \mathrm{N} / \mathrm{mm}^{2} \\
\text { Modul } 100 \%, \mathrm{~N} / \mathrm{mm}^{2}\end{array}$ & 3.79 & 2.03 & 0.47 & 3.32 & 4.26 \\
\hline $\begin{array}{l}300 \% \text { modulus, } \mathrm{N} / \mathrm{mm}^{2} \\
\text { Modul } 300 \%, \mathrm{~N} / \mathrm{mm}^{2}\end{array}$ & 9.91 & 2.10 & 0.60 & 9.31 & 10.51 \\
\hline $\begin{array}{l}\text { Tensile strength, } \mathrm{N} / \mathrm{mm}^{2} \\
\text { Rezistenţa la rupere, } \mathrm{N} / \mathrm{mm}^{2}\end{array}$ & 11.90 & 2.03 & 4.80 & 7.10 & 16.71 \\
\hline $\begin{array}{l}\text { Elongation at break, } \% \\
\text { Alungirea la rupere, } \%\end{array}$ & 544.24 & 2.03 & 0.34 & 543.90 & 544.57 \\
\hline $\begin{array}{l}\text { Residual elongation, } \% \\
\text { Alungire remanentă, \% }\end{array}$ & 287.26 & 2.03 & 0.59 & 286.67 & 287.85 \\
\hline $\begin{array}{c}\text { Tear strength, } \mathrm{N} / \mathrm{mm} \\
\text { Rezistenţă la sfâşiere, } \mathrm{N} / \mathrm{mm}\end{array}$ & 62.94 & 2.03 & 0.30 & 62.64 & 63.24 \\
\hline
\end{tabular}

* df is the number of degrees of freedom corresponding to the residual variance taken from the corresponding ANOVA table

*df reprezintă numărul de grade de libertate corespunzător variaţiei reziduale preluat din tabelul ANOVA corespunzător 
Table 6: Estimation of blend characteristics for $15 \mathrm{Mrad}$

Tabelul 6: Estimarea caracteristicilor amestecului pentru $15 \mathrm{Mrad}$

\begin{tabular}{|c|c|c|c|c|c|}
\hline \multirow{2}{*}{$\begin{array}{l}\text { Characteristic } \\
\text { Caracteristică }\end{array}$} & \multirow{2}{*}{$\begin{array}{l}\text { Estimated value } \\
\text { Valoare estimată }\end{array}$} & \multirow{2}{*}{$t^{*}{ }_{\alpha / 2, d f}$} & \multirow{2}{*}{$\begin{array}{l}\text { Limit of error } \\
\text { Eroare limită }\end{array}$} & \multicolumn{2}{|c|}{$\begin{array}{l}\text { Confidence interval } \\
\text { Interval de încredere }\end{array}$} \\
\hline & & & & $\begin{array}{l}\text { Lower limit } \\
\text { Limita inferioară }\end{array}$ & $\begin{array}{l}\text { Upper limit } \\
\text { Limita superioară }\end{array}$ \\
\hline $\begin{array}{l}\text { Hardness, ShA } \\
\text { Duritate, ShA }\end{array}$ & 84.40 & 2.03 & 3.85 & 80.55 & 88.25 \\
\hline $\begin{array}{l}100 \% \text { modulus, } \mathrm{N} / \mathrm{mm}^{2} \\
\text { Modul } 100 \%, \mathrm{~N} / \mathrm{mm}^{2}\end{array}$ & 3.81 & 2.03 & 0.47 & 3.33 & 4.28 \\
\hline $\begin{array}{l}300 \% \text { modulus, } \mathrm{N} / \mathrm{mm}^{2} \\
\text { Modul } 300 \%, \mathrm{~N} / \mathrm{mm}^{2}\end{array}$ & 11.69 & 2.10 & 0.61 & 11.09 & 12.30 \\
\hline $\begin{array}{l}\text { Tensile strength, } \mathrm{N} / \mathrm{mm}^{2} \\
\text { Rezistenţa la rupere, } \mathrm{N} / \mathrm{mm}^{2}\end{array}$ & 9.35 & 2.03 & 4.84 & 4.51 & 14.18 \\
\hline $\begin{array}{l}\text { Elongation at break, } \% \\
\text { Alungirea la rupere, } \%\end{array}$ & 538.80 & 2.03 & 0.34 & 538.46 & 539.14 \\
\hline $\begin{array}{l}\text { Residual elongation, } \% \\
\text { Alungire remanentă, } \%\end{array}$ & 282.37 & 2.03 & 0.59 & 281.78 & 282.97 \\
\hline $\begin{array}{l}\text { Tear strength, } \mathrm{N} / \mathrm{mm} \\
\text { Rezistenţă la sfâşiere, } \mathrm{N} / \mathrm{mm}\end{array}$ & 62.52 & 2.03 & 0.30 & 62.22 & 62.82 \\
\hline
\end{tabular}

$* \mathrm{df}$ is the number of degrees of freedom corresponding to the residual variance taken from the corresponding ANOVA table

*df reprezintă numărul de grade de libertate corespunzător variaţiei reziduale preluat din tabelul ANOVA corespunzător

\section{CONCLUSIONS}

Analyzing characteristics of EVA and TAC blends irradiated with EB, it can be concluded that the optimal dose of crosslinking is in the range of 7-14 Mrad, but irradiation dose necessary for crosslinking and grafting is chosen depending on the desired physical and mechanical properties. Comparing physical and mechanical characteristics of the samples irradiated at the same irradiation dose and irradiated control samples (crosslinked with peroxides), it is found that they are reproducible, that the desired effect is achieved (crosslinking and grafting), demonstrating the functionality and usefulness of the crosslinking and grafting technology with EB.

Experimental data were statistically analyzed and processed and a separate analysis was performed for each feature. A regression model was validated for each feature separately, synthesizing the way in which

\section{CONCLUZII}

Analizând caracteristicile amestecurilor de EVA şi TAC iradiate cu EA, se poate concluziona că doza optimă de reticulare poate fi considerată în intervalul 7-14 Mrad, însă alegerea dozei de iradiere necesară grefării şi reticulării se face în funcţie de proprietăţile fizicomecanice pe care dorim să le obţinem. Comparând caracteristicile fizico-mecanice ale probelor iradiate la aceeaşi doză de iradiere, precum şi probele iradiate cu cele martor (reticulate cu peroxizi), se observă că acestea sunt reproductibile, că se obţin efectele dorite (reticularea şi grefarea), demonstrând astfel funcţionalitatea şi utilitatea tehnologiei de reticulare şi grefare cuEA.

Datele experimentale au fost analizate şi prelucrate statistic şi s-a efectuat o analiză distinctă pentru fiecare caracteristică. A fost validat câte un model de regresie pentru fiecare caracteristică în parte 
the feature changes depending on the dose of electron beam irradiation. Based on validated regression models physical-mechanical properties of EVA and TAC blends were estimated for different irradiation doses.

The results obtained demonstrated that the technology for grafting and crosslinking EVA and TAC polyfunctional monomer blends by electron beam irradiation is reproducible and reliable. care să sintetizeze modul în care caracteristica se modifică în funcţie de doza de iradiere cu electroni acceleraţi. Pe baza modelelor de regresie validate au fost estimate proprietăţile fizico-mecanice ale amestecurilor de EVA şi TAC pentru diferite doze de iradiere.

Rezultatele obţinute au demonstrat faptul că tehnologia de grefare şi reticulare a amestecurilor de EVA şi monomer polifunç̧ional TAC prin iradiere $c u$ electroni acceleraţi este reproductibilă şi fiabilă.

\section{REFERENCES}

1. Abdel-Bary, E.M., El Nesr, E.M., "Radiation-Induced Grafting of Acrylonitrile onto EPDM and BR Blended with LDPE", Kautschuk Gummi Kunststoffe, 1998, 51, 9, 593-597.

2. Woods, R., Pikaev, A., Applied Radiation Chemistry Processing, John Wiley \&Sons, Inc., New York, 1994.

3. Jinhua, W., Yoshii, F., Makuuchi, K., Radiation Vulcanization of ethylene-propylene rubber with polyfunctional monomers, Radiat Phys Chem, 2001, 60, 1-2, 139-142.

4. Zuga, M.D., lovu, H., Trandafir, V., Manaila, E., Martin, D., Stelescu, M.M., Study on the preparation of some biocomposites based on silicone elastomers and collagen, J Optoelectron Adv M, 2007, 9, 11, 3325-3329.

5. Cheng, L., Kerluke, D.R., "Radiation processing for modification of polymers", The 2003 Annual Technical Conference of Society Engineering (ANTEC), 2003, 61, 3, 2694-2699.

6. Stelescu, M.D., Niculescu-Aron, I.G., Manaila, E., Processing and Statistical Analysis of the Experimental Data Resulted from EPDM Rubber Grafting and Crosslinking with Accelerated Electrons in the Presence of TMPT, Materiale Plastice, 2009, 46, 1, 48-52.

7. Manaila, E.N., Zuga, M.D.T., Martin, D.I., Craciun, G.D., Ighigeanu, D.I., Matei, C.I., Radiation processing of rubber mixtures with polyfunctional monomers, Proceedings of the 11th international conference on optimization of electrical and electronic equipment, 2008, 125-130.

8. Manaila, E., Martin, D., Zuga, D., Craciun, G., Ighigeanu, D., Matei, C., Ethylene-propylene terpolymer rubber processing by electron beam irradiation, Sixth International Conference of the Balkan Physical Union, AIP Conference Proceedings, 2007, 899, 785.

9. Timis, D.M., Cincu, C., Bradley, D.A., Craciun, G., Mateescu, E., "Modification of some properties of polyamide-6 by electron beam induced grafting", Appl. Radiat. Isotopes., 2000, 53, 4-5, 937-944.

10. Stelescu, M.D., Manaila, E, Craciun, G., "Vulcanization of ethylene-propyleneterpolymer-based rubber mixtures by radiation processing", J. Appl. Polymer Sci., 2013, 128, 4, 2325-2336.

11. Stelescu, M.D., Manaila, E., Craciun, G., Zuga, N., "Crosslinking and grafting ethylene vinyl acetate copolymer with accelerated electrons in the presence of polyfunctional monomers", Polym. Bull., 2012, 68, 1, 263-285.

12. Isaic-Maniu, Al., Vodă, V. Gh., Statistical design of experimental data (in Romanian), Economic Press, Bucharest, 2006, 27.

13. Danciu, A.R., Niculescu-Aron, I.G., Gruiescu, M., Statistics and Econometry (in Romanian), Enciclopedic Press, Bucharest, 2007, 305-345. 
14. Niculescu-Aron, I.G., Mazurencu-Marinescu, M., Econometric methods for business (in Romanian), ASE Press, 220, Bucharest, 2007.

15. Deselnicu, D.C., Applications of Statistical Methods in Investigating Heritage Leather Items, Revista de Pielarie Incaltaminte (Leather and Footwear Journal), 2010, 10, 1, 13-30. 